\title{
Sudden developing convulsion during interscalene block: Does propofol anesthesia diminish plasma bupivacaine level?
}

\author{
Interskalen blok strasında ani gelişen konvïlsiyon: \\ Propofol anestezisi plazma bupivakain düzeyini azaltır mu?
}

\author{
İrfan GÜNGÖR, ${ }^{1}$ Burcu AKBAŞ, ${ }^{1}$ Kadir KAYA, ${ }^{1}$ Hülya ÇELEBI,, ${ }^{1}$ Uğur TAMER ${ }^{2}$
}

\begin{abstract}
Summary
We aim to review local anesthetic systemic toxicity (LAST) due to suddenly developing convulsion during interscalene block in a 67-year-old patient undergoing shoulder surgery.

Key words: Interscalane block; local anesthetic systemic toxicity (LAST).
\end{abstract}

\section{Özet}

Altmış yedi yaşında omuz rotator kaf yırtığı nedeniyle artroskopik omuz cerrabisi planlanan hastada interskalen blok uygulaması sirasinda gelişen konvülziyon nedeniyle lokal anestezik sistemik toksisitesi (LAST) derlenmiştir.

Anahtar Kelimeler: Interskalen blok; lokal anestezik sistemik toksisitesi (LAST).

\section{Introduction}

Interscalene block with proximal approach to brachial plexus is a commonly utilized procedure for shoulder surgery. ${ }^{[1]}$ Because of the rich vascular supply of the block site, high volume of local anesthetic administration and resulting fast absorption, high plasma concentrations do occur ${ }^{[2]}$ and systemic toxic reaction possibility due to unintentional intravascular injection is also high. ${ }^{[3,4]}$ In this case report, local anesthetic systemic toxicity is reviewed due to suddenly developing convulsion during interscalene block. Written informed consent has been obtained from the patient for publication of this report.

\section{Case Report}

Sixtyseven-year-old, $66 \mathrm{~kg}$ female patient was seen at preoparative visit for shoulder arthroscopic surgery due to rotator cuff rupture. She was using medications for her diabetes mellitus and hypertension, and had no previous surgery or drug allergy history. All the laboratuvary exam was in normal limits. The patient was monitorised at the operation room. Her non-invasive blood pressure measurement was 160/94 $\mathrm{mmHg}$, heart rate was 63 beat per min and peripheral oxygen saturation was $96 \%$. 1 mg midazolam and $50 \mu \mathrm{g}$ fentanyl were administered intravenously for sedation before the procedure. Appropiate block position was given to the neck and needle entry site was marked with a help of pen (Stimuplex ${ }^{\oplus}$ Pen, B. Braun Melsungen AG, Germany). Skin was prepared with antiseptic and entry site was infiltrated with $1 \mathrm{~mL} 2 \%$ lidocaine. Nerve stimulator (Stimuplex ${ }^{\oplus}$ HNS 12, B. Braun

\footnotetext{
'Department of Anesthesiology and Reanimation, Gazi University Faculty of Medicine, Ankara, Turkey; ${ }^{2}$ Department of Analytic Chemistry, Gazi University Faculty of Pharmacy, Ankara, Turkey

'Gazi Üniversitesi Tıp Fakültesi, Anesteziyoloji ve Reanimasyon Anabilim Dalı, Ankara;

${ }^{2}$ Gazi Üniversitesi Tıp Fakültesi, Eczacılık Fakültesi, Analitik Kimya Bölümü, Ankara

Submitted (Başvuru tarihi) 18.01.2013 Accepted after revision (Düzeltme sonrası kabul tarihi) 05.09.2013
}

Correspondence (İletişim): Dr. İran Güngör. Gazi üniversitesi Tıp Fakültesi, Anesteziyoloji Anabilim Dalı, Besevler 06500, Ankara, Turkey.

Tel: +90 - 312- 2025319 e-mail (e-posta): irserkez@yahoo.co.uk 
Melsungen AG, Germany) was adjusted to $2 \mathrm{~mA}$ currency, $0.1 \mathrm{~ms}$ duration and a frequency of $1 \mathrm{~Hz}$. $23 \mathrm{G}$ Block needle $(50 \mathrm{~mm}$, insulated short bevel, Top Neuropole Needle-XE-Tokyo, Japan) was introduced into interscalene groove and advanced with medial-caudal-posterior direction until contractions on the deltoid muscle are obtained. When appropiate response was obtained at $0.3 \mathrm{~mA}, 0.375 \% \mathrm{bu}-$ pivacaine solution was administered with intermittant injection technique, repeating the aspiration in every $5 \mathrm{~mL}$. Continuous verbal communication with the patient was preserved during the injection process. Although the aspiration test was negative at the end of $25 \mathrm{~mL}$ injection, verbal communication with the patient was suddenly lost while injecting the last fraction and tonic-clonic convulsions began within seconds. Ventilatory support with $100 \%$ oxygen was initiated immediately, heart rate was 140 bpm, non-invasive blood pressure 190/105 $\mathrm{mmHg}$ and peripheral oxygen saturation was $96 \%$ at that moment. In order to control the seizures and induce anesthesia $500 \mathrm{mg}$ thiopental and $40 \mathrm{mg}$ atracurium were administered intravenously. After the intubation, hemodynamic variables were stable at the patient, general anesthesia was maintained with 4-6 $\mathrm{mg} / \mathrm{kg} / \mathrm{hr}$ propofol (Diprivan ${ }^{\oplus}$, AstraZeneca, Istanbul) and $0.15-0.2 \mu \mathrm{g} / \mathrm{kg} / \mathrm{min}$ remifentanil (Ultiva ${ }^{\circ}$, Glaxo Smithkline, Istanbul) intravenous infusion. In order to detect the plasma concentration of bupivacaine, blood samples were drawn from the patient just after the intubation and at the conclusion of surgery which lasted $135 \mathrm{~min}$. There was no signs of arrythmia within the intraoperative period, surgery was uneventful and the patient was extubated at the end of surgery without any further problem. Postoperative anesthesia care unit follow-up of the patient in the next hour was within the normal limits, her hemodynamics were stable with no sign of arrythmia or confusion; she was sent to orthopedics ward. The next 24 hour follow-up was uneventful again and the patient was discharged home following her therapy.

Plasma bupivacaine concentration was determined with HPLC system HP 1050 serial model UV-VIS detector (wave size $219 \mathrm{~nm}$. A henomenex C-18 colon $250 \mathrm{~mm} \times 4 \mathrm{~mm}$. i.d, $5 \mu \mathrm{m}$ particule size) and HP 3396 integrator. Plasma samples were prepared with the method described by Gross et al. ${ }^{[5]}$ and in- jected to system. Plasma bupivacaine level was 1.664 $\mu \mathrm{g} / \mathrm{mL}$ at the first sample whereas bupivacaine was not found in the second sample.

\section{Discussion}

Cardiovascular collapse, Horner syndrome, recurrent and phrenic nerve palsy, bronchospasm, total spinal anesthesia, epidural anesthesia, pneumothorax and intravascular injection are among the expected complications during or after the interscalene brachial plexus blockade. ${ }^{[6]}$ Since the possibility of intravascular injection is high at the sites rich in vascularity, local anesthetic systemic toxicity (LAST) may be inevitable even though appropiate precautions. ${ }^{[7]}$ It is important to preserve verbal communication with the patient and avoid deep sedation for early detection of clinical LAST signs. Although continuation of communication with our patient is a sign of appropiately conscious sedation, variability of responds for each patient should not be ignored.

Kiuchi et al., ${ }^{[8]}$ has demonstrated that development of systemic toxicity possibility is lower in young rats and emphasized on the age. Although our patient was older, we are in the opinion that this complication was rather due to the block site. Sudden development of convulsions without preceeding alerting signs led us to think inadvertent intra-arterial injection. Performing the procedure at the operation theatre where all monitorization and resuscitation equipment is available and rapid initiation of therapeutic steps has increased the possibility of preserving life of the patient. Nishiyama and Komatsu, ${ }^{[2]}$ has stated that convulsions seen at the 10th min of interscalene block in a sedated 72 years old female patient might be due to injection into a small vein in the area and negative aspiration test could be the result of a needle touching to the vein wall. Dhir et al., ${ }^{[9]}$ had reported that the convulsions that appear 15 min after the injection of local anesthetic might be due to systemic absorption but found out that the catheter was located intravascularly when investigated with doppler device. In general, intravenous injections cause to late reactions depending on the dose during the interscalene block; still very small dose administered intra-arterially may lead to serious reactions. 
Frequency of LAST development during peripheral nerve blocks has been reported to be $0.025 \% .^{[10]}$ In a retrospective evaluation, central nervous system (CNS) toxicity frequency was $0.76 \%$ within 659 interscalene blocks, whereas cardiovascular toxicity was rare. ${ }^{[1]}$ Aside from bupivacaine, other potent amide group local anesthetics ropivacaine and levobupivacaine are reported to lead to convulsions in the literature. ${ }^{[12,13]}$

It has been emphasized by Groban, ${ }^{[14]}$ that none of the local anesthetics is safe and clinical followup should have priority. In general, it is accepted that plasma concentration of bupivacaine leading to cardiovascular toxicity is $2-4 \mu \mathrm{g} / \mathrm{mL} \cdot{ }^{[15,16]}$ But in an experiment on cats, de Jong et al. ${ }^{[17]}$ has determined convulsions at $5.3 \pm 2.1 \mathrm{~min}$ and $3.6 \pm 0.7 \mu \mathrm{g} / \mathrm{mL}$ for bupivacaine infusion. In a study conducted on volunteers, threshold plasma concentration of bupivacaine that produces CNS toxicity was reported to be $2.1 \mu \mathrm{g} / \mathrm{mL} .{ }^{[18]}$ However in the presented case, total plasma concentration of bupivacaine at the blood sample drawn after intubation was $1.664 \mu \mathrm{g} / \mathrm{mL}$, and this value was lower than the previously reported threshold level for convulsions. The convulsion in this patients is most probably due to intraarterial injection but still, increase in plasma concentration of bupivacaine by absorption by surrounding vascular structure may also have contributed to the scene. Thus, Ichikawa et al. ${ }^{[4]}$ had reported a generalized convulsion during interscalene block procedure which developed 3 min later despite negative aspiration. Disappearence of bupivacaine in the second blood sample despite short (135 min) duration between two blood sampling times is thought to resulting from lower total administered bupivacaine dose $(1.7 \mathrm{mg} / \mathrm{kg})$ than the generally accepted maximum dose $(2 \mathrm{mg} / \mathrm{kg})$.

The beneficial affects of lipid emulsions in the treatment of cardiac arrest due to local anesthetics have been demonstrated and "Lipid Rescue" has its place in LAST treatment protocol. ${ }^{[19-22]}$ In addition, it has been experimantally demonstrated that lipid emulsion pretreatment diminishes bupivacaine associated cardiotoxicity. ${ }^{[23]}$ Though intralipids are used for resuscitations, there are studies demonstrating propofol can be useful for preventive or protective treatment. Ohmura et al., ${ }^{[24]}$ has proposed that propofol could be protective against cardiodepressive affects of bupivacaine. In a similar experimental study, it was reported that pretreatment with propofol including 10\% intralipid delays the cardiodepressant effects of bupivacaine and elevates the threshold for asystole development. ${ }^{[25]}$ Authors of this study have demonstrated that tissue and plasma bupivacaine levels were decreased in comparison with control values and emphasized the protective affect of propofol. On the other hand, there is a case report in literature which reports beneficial affect of propofol administration when CNS symptoms or convulsions appear. ${ }^{[26]}$

Plasma elimination half-life of bupivacaine is 162 $\min .{ }^{[27]}$ In this case where we used propofol for anesthesia maintanence, although the patient is older, undetection of bupivacaine in the second blood sample drawn 135 min later, has led to us to think that propofol increases elimination speed of bupivacaine from plasma.

In summary, although interscalene block has many advantages for shoulder surgery, it shouldn't be forgotten that it has a high complication rate. If general anesthesia is needed when convulsions appears, preference for propofol anesthesia will be useful for decreasing plasma local anesthetic level. Additionally, anesthesiologist should be ready for all kinds of complications in peripheral nerve block applications; standard resuscitation sets should include 20\% intralipid solution and instruction manual as American Society of Regional Anesthesia recommends.

\section{Conflict-of-interest issues regarding the author- ship or article: None declared.}

\section{Peer-rewiew: Externally peer-reviewed.}

\section{References}

1. Winnie AP. Interscalene brachial plexus block. Anesth Analg 1970;49(3):455-66. CrossRef

2. Nishiyama T, Komatsu K. Local anesthetic toxicity in interscalene block: clinical series. Minerva Anestesiol 2010;76(12):1088-90.

3. Müller M, Litz RJ, Hüler M, Albrecht DM. Grand mal convulsion and plasma concentrations after intravascular injection of ropivacaine for axillary brachial plexus blockade. $\mathrm{Br} J$ Anaesth 2001;87(5):784-7. CrossRef

4. Ichikawa M, Ishiyama T, Shibuya K, Okawa I, Matsukawa T. Grand mal convulsion after an interscalene block with ropi- 
vacaine. [Article in Japanese] Masui 2009;58(4):467-9. [Abstract]

5. Gross AS, Nicolay A, Eschalier A. Simultaneous analysis of ketamine and bupivacaine in plasma by high-performance liquid chromatography. J Chromatogr B Biomed Sci Appl 1999;728(1):107-15. CrossRef

6. Misamore G, Webb B, McMurray S, Sallay P. A prospective analysis of interscalene brachial plexus blocks performed under general anesthesia. J Shoulder Elbow Surg 2011;20(2):308-14. CrossRef

7. Mulroy MF, Hejtmanek MR. Prevention of local anesthetic systemic toxicity. Reg Anesth Pain Med 2010;35(2):177-80.

8. Kiuchi MG, Zapata-Sudo G, Trachez MM, Ririe D, Sudo RT. The influence of age on bupivacaine cardiotoxicity. Anesth Analg 2011;112(3):574-80. CrossRef

9. Dhir S, Ganapathy S, Lindsay P, Athwal GS. Case report: ropivacaine neurotoxicity at clinical doses in interscalene brachial plexus block. Can J Anaesth 2007;54(11):912-6. CrossRef

10. Auroy Y, Benhamou D, Bargues L, Ecoffey C, Falissard B, Mercier $\mathrm{FJ}$, et al. Major complications of regional anesthesia in France: The SOS Regional Anesthesia Hotline Service. Anesthesiology 2002;97(5):1274-80. CrossRef

11. Brown DL, Ransom DM, Hall JA, Leicht $C H$, Schroeder DR, Offord KP. Regional anesthesia and local anesthetic-induced systemic toxicity: seizure frequency and accompanying cardiovascular changes. Anesth Analg 1995;81(2):321-8. CrossRef

12. Satsumae $T$, Tanaka $M$, Saito $S$, Inomata $S$. Convulsions after ropivacaine $300 \mathrm{mg}$ for brachial plexus block. Br J Anaesth 2008;101(6):860-2. CrossRef

13. Crews JC, Rothman TE. Seizure after levobupivacaine for interscalene brachial plexus block. Anesth Analg 2003;96(4):1188-90. CrossRef

14. Groban L. Central nervous system and cardiac effects from long-acting amide local anesthetic toxicity in the intact animal model. Reg Anesth Pain Med 2003;28(1):3-11. CrossRef

15. Denson DD, Myers JA, Hartrick CT, Pither CP, Coyle DE, Raj PP. The relationship between free bupivacaine concentration and central nervous system toxicity. Anesthesiology 1984;61:A211. CrossRef

16. Tucker GT, Mather LE. Clinical pharmacokinetics of local an- aesthetics. Clin Pharmacokinet 1979;4(4):241-78. CrossRef

17. de Jong RH, Ronfeld RA, DeRosa RA. Cardiovascular effects of convulsant and supraconvulsant doses of amide local anesthetics. Anesth Analg 1982;61(1):3-9. CrossRef

18. Knudsen K, Beckman Suurküla M, Blomberg S, Sjövall J, Edvardsson N. Central nervous and cardiovascular effects of i.v. infusions of ropivacaine, bupivacaine and placebo in volunteers. Br J Anaesth 1997;78(5):507-14. CrossRef

19. Weinberg GL. Current concepts in resuscitation of patients with local anesthetic cardiac toxicity. Reg Anesth Pain Med 2002;27(6):568-75. CrossRef

20. Turner-Lawrence DE, Kerns li W. Intravenous fat emulsion: a potential novel antidote. J Med Toxicol 2008;4(2):109-14.

21. Ozcan MS, Weinberg G. Update on the use of lipid emulsions in local anesthetic systemic toxicity: a focus on differential efficacy and lipid emulsion as part of advanced cardiac life support. Int Anesthesiol Clin 2011;49(4):91-103. CrossRef

22. Neal JM, Bernards CM, Butterworth JF 4th, Di Gregorio G, Drasner K, Hejtmanek MR, et al. ASRA practice advisory on local anesthetic systemic toxicity. Reg Anesth Pain Med 2010;35(2):152-61. CrossRef

23. Weinberg GL, VadeBoncouer T, Ramaraju GA, Garcia-Amaro MF, Cwik MJ. Pretreatment or resuscitation with a lipid infusion shifts the dose-response to bupivacaine-induced asystole in rats. Anesthesiology 1998;88(4):1071-5. CrossRef

24. Ohmura S, Ohta T, Yamamoto K, Kobayashi T. A comparison of the effects of propofol and sevoflurane on the systemic toxicity of intravenous bupivacaine in rats. Anesth Analg 1999;88(1):155-9. CrossRef

25. Yılmaz M, Çelebi H, Akcali D, Gurel N. Pretreatment with different lipid formulations of propofol for bupivacaine indused cardiotoxicity. 30th Annual ESRA Congress 2011, Dresden, Germany, Free Communications, September 7-10, 2011; pp. 15.

26. Bishop D, Johnstone RE. Lidocaine toxicity treated with lowdose propofol. Anesthesiology 1993;78(4):788-9. CrossRef

27. Büttner J, Meier G. Pharmakologie und Toxikologie der Lokalanästhetika. In: Kontunuierliche periphere Techniken zur Regionalanästhesie und Schmerztherapie-Obere und untere Extremität. Uni-MED Bremen. 1. Auflage, 1999;27. 